www.nature.com/pj

\title{
Synthesis of aromatic poly(ether ketone)s bearing optically active macrocycles through Suzuki coupling polymerization
}

\author{
Katsuya Maeyama ${ }^{1}$, Kenji Yamashita ${ }^{2}$, Hiromu Saito $^{2}$, Shunichi Aikawa ${ }^{3}$ and Yasuhiko Yoshida ${ }^{3}$ \\ Palladium (Pd)-catalyzed Suzuki coupling polymerization of macrocycle-bearing monomers, obtained through two-step \\ nucleophilic aromatic substitution reactions with three types of diboric acid pinacol esters, produced aromatic poly(ether \\ ketone)s that have optically active macrocycles composed of two $2,2^{\prime}$-dioxy-1,1'-binaphthyl-6,6'-diyl units and two aromatic \\ ether ketone linkers. The macrocycle-bearing aromatic poly(ether ketone)s have excellent thermal and optical properties, that is, \\ high glass-transition temperatures $\left(T_{\mathrm{g}:}: 220-257^{\circ} \mathrm{C}\right)$ and large molar rotations $\left([\Phi]^{25}:+1906-1976 \mathrm{deg}\right)$. In addition, \\ polyketones have excellent solubility in typical solvents such as $\mathrm{CHCl}_{3}$ and $\mathrm{N}, \mathrm{N}$-dimethylformamide (DMF). \\ Polymer Journal (2012) 44, 315-320; doi:10.1038/pj.2011.134; published online 11 January 2012
}

Keywords: aromatic poly(ether ketone)s; excellent solubility; macrocycles; Suzuki coupling polymerization; thermal stability

\section{INTRODUCTION}

Aromatic poly(ether ketone)s, which consist of aromatic rings, ketone groups and ether units, have drawn much attention as physically and chemically stable organic materials. ${ }^{1-3}$ In particular, poly(ether ether ketone) is well known as one of the great engineering plastics. We synthesized aromatic poly(ether ketone) $\mathrm{s}^{4-6}$ and wholly aromatic polyketones ${ }^{7,8}$ containing optically active $2,2^{\prime}$-dioxy-1,1'-binaphthyl$6,6^{\prime}$-diyl units. These polymers have high chemical stability and excellent solubility in organic solvents such as $\mathrm{CHCl}_{3}$ and DMF. Furthermore, we developed aromatic polyketones containing optically active macrocycles ${ }^{9-13}$ composed of $1,1^{\prime}$-binaphthyl-2,2'-dioxy units. ${ }^{14,15}$ These macrocycle-bearing polymers have adequate thermal and optical properties and solubility for use in engineering applications.

In a previous paper, we reported on the synthesis of three types of optically active macrocycles consisting of $2,2^{\prime}$-dimethoxy- $1,1^{\prime}$ binaphthyl-6, $6^{\prime}$-diyl units and aromatic ether ketone linkers through a stepwise nucleophilic aromatic substitution reaction. ${ }^{16}$ The resulting macrocycles have high molar rotations.

In this paper, we report on the synthesis of poly(ether ketone)s containing optically active macrocycles composed of $1,1^{\prime}$-binaphthyl6,6'-diyl units through palladium $(\mathrm{Pd})\left(\mathrm{PPh}_{3}\right)_{4}$-catalyzed Suzuki coupling polymerization ${ }^{17}$ of macrocycle-bearing dibrominated monomer 10 with diboric acid esters 11a-c. Thermal and optical properties and solubility in organic solvents of the resulting poly(ether ketone)s (12) are also described.

\section{EXPERIMENTAL PROCEDURE}

Materials

(S)-1,1'-Bi-2-naphthol (BINOL, 1) was purchased from Kanto Chemical (Tokyo, Japan). 4-Bromodiphenyl ether (2), 4-fluorobenzoic acid and 4,4'-oxybiphenol (8) were purchased from Tokyo Kasei Kogyo (Tokyo, Japan). Aluminum chloride, potassium carbonate and pinacol were purchased from Wako Pure Chemical Industries (Osaka, Japan). Methanesulfonic acid $(\mathrm{MsOH})$ was purchased from Aldrich. (St Louis, MO, USA) $\mathrm{Pd}\left(\mathrm{PPh}_{3}\right)_{4}$ was purchased from Nacalai Tesque (Kyoto, Japan). These reagents were used as received. DMF was purchased from Kanto Chemical and used after distillation under reduced pressure. 4-Fluorobenzoyl chloride (3) was provided by Ihara Nikkei Chemical Industry (Shizuoka, Japan). Diboric acid pinacol esters 11a-c were prepared through esterification of the corresponding diboric acids with pinacol. Diboric acids were prepared through lithiation of the corresponding diiodide or dibromide, followed by transmetallation by trimethoxyborane and acidic workup according to typical procedures.

\begin{abstract}
Instruments
${ }^{1} \mathrm{H}$-nuclear magnetic resonance (NMR) spectra were obtained using Jeol JNMAL-300 (Jeol, Tokyo, Japan; 300 MHz) and Jeol JNM-ECX-400 (400 MHz). Chemical shifts are expressed in p.p.m. relative to the internal standard of $\mathrm{Me}_{4} \mathrm{Si}(\delta, 0.00) .{ }^{13} \mathrm{C}-\mathrm{NMR}$ spectra were obtained using Jeol JNM-AL-300 $(75 \mathrm{MHz})$ and Jeol JNM-ECX-400 $(100 \mathrm{MHz})$. Chemical shifts are expressed in p.p.m. relative to the internal standard of $\mathrm{CDCl}_{3}(\delta, 77.0)$. Infrared (IR) measurements were obtained using Jeol FT/IR-4100. Recycling preparative high-performance liquid chromatography (HPLC) was performed using $\mathrm{CHCl}_{3}$ as an eluent using JAI LC-9201 (JAI, Tokyo, Japan) equipped with a ultraviolet
\end{abstract}

${ }^{1}$ Department of Polymer Science and Engineering, Graduate School of Science and Engineering, Yamagata University, Yonezawa, Yamagata, Japan; ${ }^{2}$ Department of Organic and Polymer Materials Chemistry, Graduate School of Technology, Tokyo University of Agriculture and Technology, Koganei, Tokyo, Japan and ${ }^{3}$ Bio-Nano Electronics Research Center, Toyo University, Kujirai, Kawagoe, Japan

Correspondence: Professor K Maeyama, Department of Polymer Science and Engineering, Graduate School of Science and Engineering, Yamagata University, 4-3-16 Jonan, Yonezawa, Yamagata 992-8510, Japan.

E-mail: maeyama@yz.yamagata-u.ac.jp

Received 1 September 2011; revised 18 October 2011; accepted 6 November 2011; published online 11 January 2012 
detector $(254 \mathrm{~nm})$ and JAIGEL $2.5 \mathrm{H}$ and $3 \mathrm{H}$ gel-permeation chromatography columns. Molar rotations $\left([\phi]_{\mathrm{D}}^{25}\right)$ were determined in $\mathrm{CHCl}_{3}\left(5 \times 10^{-5} \mathrm{moll}^{-1}\right)$ using a Jasco DIP-1000 digital polarimeter (Jasco, Tokyo, Japan). Circular dichromism $(\mathrm{CD})$ measurements were performed in $\mathrm{CHCl}_{3}\left(2 \times 10^{-5} \mathrm{moll}^{-1}\right.$, c: $1 \mathrm{~cm}$ ) using Jasco J820. MALDI-TOF MS (matrix-assisted laser desorption/ ionization-time of flight mass spectrometry) spectra were obtained using a Bruker Autoflex II TOF/TOF mass spectrometer (Bruker, Karlsruhe, Germany). The spectrometer was equipped with a nitrogen laser $(\lambda=337 \mathrm{~nm})$, a pulsed ion-extraction system and a reflector; the operation was performed at an accelerating potential of $20 \mathrm{kV}$ in positive ion mode. $\mathrm{A} \mathrm{CHCl}_{3}$ solution of macrocycle $10\left(1 \mu \mathrm{mol} \mathrm{ml}^{-1}, 3 \mu \mathrm{l}\right)$ was mixed with a $\mathrm{CHCl}_{3}$ solution of 1,8 dihydroxy- $9(10 \mathrm{H})$ anthracenone (the matrix, dithranol, Aldrich) $\left(10 \mathrm{mg} \mathrm{ml}^{-1}\right.$, $8 \mu \mathrm{l})$. A 1-ml portion of the mixed solution was deposited onto a ground-steel sample target and allowed to dry in air at room temperature. Mass values were calibrated with peptide calibration standards purchased from Bruker Daltonics K.K. (Kanagawa, Japan) Gel-permeation chromatography measurements were performed at a flow rate of $1.0 \mathrm{ml} \mathrm{min}^{-1}$ at $40{ }^{\circ} \mathrm{C}$ using $\mathrm{CHCl}_{3}$ as an eluent in Jasco PU-2080 equipped with a ultraviolet detector $(190-600 \mathrm{~nm})$ and a Shodex K-804L column (Shodex, Tokyo, Japan). Glass transition temperatures $\left(T_{\mathrm{g}} \mathrm{s}\right)$ were determined using differential scanning calorimetry (DSC) thermograms, which were obtained using a Rigaku DSC-8230 differential scanning calorimeter (Rigaku, Tokyo, Japan) with a heating rate of $10 \mathrm{~K} \mathrm{~min}^{-1}$. Thermal degradation temperatures $\left(T_{\mathrm{d} 5}\right)$ were determined using thermogravimetry analysis (TGA) thermograms, which were obtained using a Rigaku TG-8120 thermogravimeter with a heating rate of $10 \mathrm{~K} \mathrm{~min}^{-1}$.

$\mathrm{P}_{2} \mathrm{O}_{5}-\mathrm{MsOH}$ was prepared according to Eaton's procedure. ${ }^{18}(S)-6,6^{\prime}-\mathrm{Bis}(4-$ fluorobenzoyl)-2,2'-dimethoxy-1,1'-binaphthyl (7) was prepared according to our previous paper. ${ }^{4}$

\section{4-(4-Bromophenyloxy)-4'-fluorobenzophenone (4)}

4-Bromodiphenyl ether $(2,2.49 \mathrm{~g}, 10 \mathrm{mmol})$, 4-fluorobenzoyl chloride $(3,1.59 \mathrm{~g}, 10 \mathrm{mmol})$ and 1,2 -dichloroethane $(40 \mathrm{ml})$ were added to a $100-\mathrm{ml}$ one-necked flask. $\mathrm{AlCl}_{3}(2.67 \mathrm{~g}, 20 \mathrm{mmol})$ was then added at $0{ }^{\circ} \mathrm{C}$. The reaction mixture was stirred at room temperature for $4 \mathrm{~h}$. The mixture was poured into water in a beaker, and after the mixture was neutralized with $6 \mathrm{~m}$ aqueous sodium hydroxide, the separated aqueous layer was extracted three times using chloroform. The combined extracts were dried over anhydrous $\mathrm{MgSO}_{4}$. After removal of the drying agent, chloroform was removed under reduced pressure. The crude product was purified by recrystallization from $\mathrm{EtOH}$ to produce pure 4 as a yellow powder with $85 \%$ yield.

${ }^{1} \mathrm{H}-\mathrm{NMR} \quad \delta\left(300 \mathrm{MHz}, \mathrm{CDCl}_{3}\right): 6.97(2 \mathrm{H}, \mathrm{d}, J=8.4 \mathrm{~Hz}), \quad 7.02(2 \mathrm{H}, \mathrm{d}$, $J=8.7 \mathrm{~Hz}), 7.15(2 \mathrm{H}, \mathrm{t}, J=8.7 \mathrm{~Hz}), 7.50(2 \mathrm{H}, \mathrm{d}, J=8.4 \mathrm{~Hz}), 7.78(2 \mathrm{H}, \mathrm{d}, J=8.7 \mathrm{~Hz})$, $7.81(2 \mathrm{H}, \mathrm{dd}, J=5.4,8.7 \mathrm{~Hz})$ p.p.m. ${ }^{13} \mathrm{C}-\mathrm{NMR} \delta\left(75 \mathrm{MHz}, \mathrm{CDCl}_{3}\right): 115.4(\mathrm{~d}$, $\left.{ }^{2} J_{\mathrm{CF}}=21.8 \mathrm{~Hz}\right), 117.2,117.4,121.7,132.2,132.4\left(\mathrm{~d},{ }^{3} J_{\mathrm{CF}}=9.3 \mathrm{~Hz}\right), 133.1,133.9$, 134.0, 154.7, 161.0, $165.2\left(\mathrm{~d},{ }^{1} J_{\mathrm{CF}}=254 \mathrm{~Hz}\right), 193.9$ p.p.m. IR $v(\mathrm{KBr}): 1010$, $1156,1238,1601,1645 \mathrm{~cm}^{-1}$. Anal. calcd. for $\mathrm{C}_{19} \mathrm{H}_{12} \mathrm{BrFO}_{2}$ : C, 61.48; $\mathrm{H}, 3.26$. Found: C, 61.31; H, 3.44\%.

\section{Dibromide 5}

(S)-BINOL (1, $573 \mathrm{mg}, 2 \mathrm{mmol}$ ), 4-(4-bromophenyloxy)-4'-fluorobenzophenone $(4,2.23 \mathrm{~g}, 6 \mathrm{mmol})$, potassium carbonate $(831 \mathrm{mg}, 6 \mathrm{mmol})$ and freshly distilled DMF ( $4 \mathrm{ml}$ ) were added to a 50-ml two-necked flask. After the reaction mixture was stirred at $150^{\circ} \mathrm{C}$ for $4 \mathrm{~h}$, it was poured into water, and the resulting solid was collected by suction filtration. After $\mathrm{H}_{2} \mathrm{O}$ and chloroform were added to the solid, the separated aqueous layer was extracted three times using chloroform. The combined extracts were dried over anhydrous $\mathrm{MgSO}_{4}$. After removal of the drying agent, chloroform was removed under reduced pressure. The residue was purified by column chromatography $\left(\mathrm{CHCl}_{3}\right)$ to produce pure $\mathbf{5}$ as a yellow powder with $74 \%$ yield.

${ }^{1} \mathrm{H}-\mathrm{NMR} \delta\left(300 \mathrm{MHz}, \mathrm{CDCl}_{3}\right): 6.82(4 \mathrm{H}, \mathrm{d}, J=8.7 \mathrm{~Hz}), 6.95(4 \mathrm{H}, \mathrm{d}, J=8.4 \mathrm{~Hz})$, $6.98(4 \mathrm{H}, \mathrm{d}, J=8.4 \mathrm{~Hz}), 7.27-7.35(6 \mathrm{H}, \mathrm{m}), 7.42-7.50(6 \mathrm{H}, \mathrm{m}), 7.56(4 \mathrm{H}, \mathrm{d}$, $J=8.7 \mathrm{~Hz}), 7.67(4 \mathrm{H}, \mathrm{d}, J=8.4 \mathrm{~Hz}), 7.91(2 \mathrm{H}, \mathrm{d}, J=8.1 \mathrm{~Hz}), 7.95(2 \mathrm{H}, \mathrm{d}, J=9.0 \mathrm{~Hz})$ p.p.m. ${ }^{13} \mathrm{C}-\mathrm{NMR} \delta\left(75 \mathrm{MHz}, \mathrm{CDCl}_{3}\right): 117.1,117.4,119.8,121.6,122.7,125.3$, $125.8,126.9,128.2,130.2,130.9,131.8,132.1,132.6,133.0,134.0,151.1,154.9$, 160.6, 161.1, 193.9 p.p.m. IR $\vee(\mathrm{KBr}): 1011,1244,1602,1650 \mathrm{~cm}^{-1}$. Anal. calcd. for $\mathrm{C}_{58} \mathrm{H}_{36} \mathrm{Br}_{2} \mathrm{O}_{6}$ : C, 70.46; H, 3.67. Found: $\mathrm{C}, 70.68 ; \mathrm{H}, 3.82 \%$.

\section{Dibromide 6}

4-Fluorobenzoic acid (168 mg, $1.2 \mathrm{mmol})$ and $\mathrm{P}_{2} \mathrm{O}_{5}-\mathrm{MsOH}(1.5 \mathrm{ml})$ were added to a $30-\mathrm{ml}$ two-necked flask. The mixture was stirred at $80^{\circ} \mathrm{C}$ for $15 \mathrm{~min}$. Dibromide 5 ( $198 \mathrm{mg}, 0.2 \mathrm{mmol}$ ) was then added to the mixture. After the reaction mixture was stirred at $80^{\circ} \mathrm{C}$ for $72 \mathrm{~h}$, it was poured into water in a beaker. After the mixture was neutralized with $6 \mathrm{~m}$ aqueous sodium hydroxide, the separated aqueous layer was extracted three times using chloroform. The combined extracts were dried over anhydrous $\mathrm{MgSO}_{4}$. After removal of the drying agent, chloroform was removed under reduced pressure. The crude product was purified with preparative thin-layer chromatography (TLC, $\mathrm{CHCl}_{3}$ ) to produce pure 6 as a yellow powder with $57 \%$ yield.

${ }^{1} \mathrm{H}-\mathrm{NMR} \quad \delta\left(300 \mathrm{MHz}, \mathrm{CDCl}_{3}\right): 6.88(4 \mathrm{H}, \mathrm{d}, J=8.7 \mathrm{~Hz}), 6.96(4 \mathrm{H}, \mathrm{d}$, $J=9.0 \mathrm{~Hz}), 6.99(4 \mathrm{H}, \mathrm{d}, J=8.7 \mathrm{~Hz}), 7.22(4 \mathrm{H}, \mathrm{t}, J=8.7 \mathrm{~Hz}), 7.39(2 \mathrm{H}, \mathrm{d}, J=9.0 \mathrm{~Hz})$, $7.41(2 \mathrm{H}, \mathrm{d}, J=8.7 \mathrm{~Hz}), 7.49(4 \mathrm{H}, \mathrm{d}, J=8.7 \mathrm{~Hz}), 7.63(4 \mathrm{H}, \mathrm{d}, J=8.7 \mathrm{~Hz}), 7.70(4 \mathrm{H}$, $\mathrm{d}, J=8.7 \mathrm{~Hz}), 7.79(2 \mathrm{H}, \mathrm{dd}, J=1.5,8.7 \mathrm{~Hz}), 7.91(4 \mathrm{H}, \mathrm{dd}, J=5.1,9.0 \mathrm{~Hz})$, $8.07(2 \mathrm{H}, \mathrm{d}, J=9.0 \mathrm{~Hz}), 8.33\left(2 \mathrm{H}\right.$, s) p.p.m. ${ }^{13} \mathrm{C}-\mathrm{NMR} \delta\left(75 \mathrm{MHz}, \mathrm{CDCl}_{3}\right)$ : $115.5\left(\mathrm{~d},{ }^{2} J_{\mathrm{CF}}=21.8 \mathrm{~Hz}\right), 117.1,117.3,117.8,120.4,121.6,122.0,125.9,127.0$, $129.6,131.8,131.9,132.1,132.3,132.6,132.7,133.0,133.7,133.8,134.2,136.0$, $153.5,154.7,160.2,160.8,165.4\left(\mathrm{~d},{ }^{1} J_{\mathrm{CF}}=254 \mathrm{~Hz}\right), 193.7,194.7$ p.p.m. IR $v$ $(\mathrm{KBr}): 1011,1159,1240,1600,1654 \mathrm{~cm}^{-1}$. Anal. calcd. for $\mathrm{C}_{72} \mathrm{H}_{42} \mathrm{Br}_{2} \mathrm{~F}_{2} \mathrm{O}_{8}: \mathrm{C}$, 70.14; H, 3.43. Found: C, 70.26; H, 3.60\%.

\section{Diol 9}

(S)-6,6'-Bis(4-fluorobenzoyl)-2,2'-dimethoxy-1,1'-binaphthyl $\quad(7, \quad 279 \mathrm{mg}$, $0.5 \mathrm{mmol}), 4,4^{\prime}$-oxybiphenol $(\mathbf{8}, 606 \mathrm{mg}, 3.0 \mathrm{mmol})$, potassium carbonate $(208 \mathrm{mg}, 1.5 \mathrm{mmol})$ and freshly distilled DMF $(13.5 \mathrm{ml})$ were added to a $50-\mathrm{ml}$ one-necked flask. After the mixture was stirred at $150^{\circ} \mathrm{C}$ for $18 \mathrm{~h}$, it was poured into aqueous $0.1 \mathrm{M} \mathrm{HCl}$ in a beaker. The resulting precipitates were collected by suction filtration. After $\mathrm{H}_{2} \mathrm{O}$ and ethyl acetate were added to the solid, the separated aqueous layer was extracted three times using ethyl acetate. The combined extracts were dried over anhydrous $\mathrm{MgSO}_{4}$. After removal of the drying agent, ethyl acetate was removed under reduced pressure. The residue soluble in $\mathrm{CHCl}_{3}$ was purified by recycling $\mathrm{HPLC}\left(\mathrm{CHCl}_{3}\right)$ to afford pure 9 as an orange powder with $45 \%$ yield.

${ }^{1} \mathrm{H}-\mathrm{NMR} \delta\left(300 \mathrm{MHz}, \mathrm{CDCl}_{3}\right): 3.80(6 \mathrm{H}, \mathrm{s}), 5.96(2 \mathrm{H}, \mathrm{brs}), 6.81(4 \mathrm{H}, \mathrm{d}$, $J=9.0 \mathrm{~Hz}), 6.83-7.03(16 \mathrm{H}, \mathrm{m}), 7.16(2 \mathrm{H}, \mathrm{d}, J=9.0 \mathrm{~Hz}), 7.51(2 \mathrm{H}, \mathrm{d}, J=9.0 \mathrm{~Hz})$, $7.65(2 \mathrm{H}, \mathrm{dd}, J=1.8,9.0 \mathrm{~Hz}), 7.84(4 \mathrm{H}, \mathrm{d}, J=9.0 \mathrm{~Hz}), 8.07(2 \mathrm{H}, \mathrm{d}, J=9.0 \mathrm{~Hz})$, $8.30(2 \mathrm{H}, \mathrm{s})$ p.p.m. ${ }^{13} \mathrm{C}-\mathrm{NMR} \delta\left(75 \mathrm{MHz}, \mathrm{CDCl}_{3}\right): 56.6,114.4,116.4,116.5$, 118.7, 119.0, 120.7, 121.6, 125.3, 126.5, 127.8, 131.5, 131.9, 132.2, 132.5, 132.8, 135.9, 150.0, 150.1, 152.2, 155.3, 156.9, 162.2, 195.8 p.p.m. IR $v(\mathrm{KBr}): 1248$, 1593, 1646, $3434 \mathrm{~cm}^{-1}$. Anal. calcd. for $\mathrm{C}_{72} \mathrm{H}_{42} \mathrm{Cl}_{2} \mathrm{~F}_{2} \mathrm{O}_{8}$ : C, 78.08; $\mathrm{H}, 4.59$. Found: C, 77.88; H, $4.68 \%$.

\section{Macrocycle-bearing monomer 10}

Potassium carbonate $(83 \mathrm{mg}, 0.6 \mathrm{mmol})$, freshly distilled DMF $(20 \mathrm{ml})$ and toluene $(4 \mathrm{ml})$ were added to a 50 -ml two-necked flask equipped with a DeanStark apparatus and a reflux condenser. The DMF solution $(5 \mathrm{ml})$ of dibromide $6(123 \mathrm{mg}, 0.1 \mathrm{mmol})$ and diol $9(184 \mathrm{mg}, 0.2 \mathrm{mmol})$ was then dropped at $150^{\circ} \mathrm{C}$ over $6 \mathrm{~h}$. The reaction mixture was stirred at $150^{\circ} \mathrm{C}$ for $72 \mathrm{~h}$. The solvent was reduced to $5 \mathrm{ml}$ under reduced pressure. The concentrated mixture was poured into water, and the resulting solid was collected by suction filtration. After $\mathrm{H}_{2} \mathrm{O}$ and chloroform were added to the solid, the separated aqueous layer was extracted three times using chloroform. The combined extracts were dried over anhydrous $\mathrm{MgSO}_{4}$. After removal of the drying agent, chloroform was removed under reduced pressure. The residue was purified with both recycling preparative HPLC and preparative TLC $\left(\mathrm{CHCl}_{3}\right)$ to produce pure $\mathbf{1 0}$ as a yellow powder with $20 \%$ yield.

${ }^{1} \mathrm{H}-\mathrm{NMR} \delta\left(400 \mathrm{MHz}, \mathrm{CDCl}_{3}\right): 3.82(6 \mathrm{H}, \mathrm{s}), 6.86(4 \mathrm{H}, \mathrm{d}, J=8.8 \mathrm{~Hz})$, 6.93-7.13 $(34 \mathrm{H}, \mathrm{m}), 7.33-7.39(4 \mathrm{H}, \mathrm{m}), 7.48(4 \mathrm{H}, \mathrm{d}, J=8.8 \mathrm{~Hz}), 7.52(2 \mathrm{H}, \mathrm{d}$, $J=8.8 \mathrm{~Hz}), 7.58(2 \mathrm{H}, \mathrm{d}, J=8.8 \mathrm{~Hz}), 7.61(4 \mathrm{H}, \mathrm{d}, J=8.8 \mathrm{~Hz}), 7.67-7.71(6 \mathrm{H}, \mathrm{m})$, $7.83(4 \mathrm{H}, \mathrm{d}, J=8.4 \mathrm{~Hz}), 7.85(4 \mathrm{H}, \mathrm{d}, J=8.4 \mathrm{~Hz}), 8.05-8.10(4 \mathrm{H}, \mathrm{m}), 8.36(2 \mathrm{H}, \mathrm{s})$, $8.38\left(2 \mathrm{H}\right.$, s) p.p.m. ${ }^{13} \mathrm{C}-\mathrm{NMR} \delta\left(100 \mathrm{MHz}, \mathrm{CDCl}_{3}\right): 56.5,114.4,116.7,117.1$, $117.3,117.7,118.7,120.0,120.1,120.4,121.6,121.7,121.8,122.0,124.9,125.6$, 126.6, 127.2, 127.9, 129.8, 131.4, 131.6, 131.9, 132.1, 132.3, 132.4, 132.5, 133.0, $134.7,135.7,150.7,150.9,153.2,153.8,154.0,154.7,156.8,160.3,160.7,161.7$, $162.1,193.7,194.9,195.2$ p.p.m. IR $\vee(\mathrm{KBr}): 1010,1241,1594,1654 \mathrm{~cm}^{-1}$. 
MALDI-TOF MASS: $m / z$ 2113.3, calcd. for $\mathrm{C}_{132} \mathrm{H}_{82} \mathrm{Br}_{2} \mathrm{O}_{18}\left([\mathrm{M}+\mathrm{H}]^{+}\right) \mathrm{m} / z$ 2113.3. Anal. calcd. for $\mathrm{C}_{132} \mathrm{H}_{82} \mathrm{Br}_{2} \mathrm{O}_{18}$ : C, 74.93; $\mathrm{H}, 3.91$. Found: $\mathrm{C}, 74.86 ; \mathrm{H}$, $3.94 \%$

\section{Macrocycle-bearing poly(ether ketone)s 12a-c}

Macrocycle-bearing monomer $10(106 \mathrm{mg}, 0.05 \mathrm{mmol})$, diboric acid pinacol diester $(11,0.05 \mathrm{mmol})$, potassium carbonate $(43 \mathrm{mg}, 0.3 \mathrm{mmol})$ and $\mathrm{Pd}\left(\mathrm{PPh}_{3}\right)_{4}(11.5 \mathrm{mg}, 0.01 \mathrm{mmol})$ were placed in a $30-\mathrm{ml}$ two-necked flask. After DMF $(0.5 \mathrm{ml})$ was added, the reaction mixture was stirred at $100^{\circ} \mathrm{C}$ for $48 \mathrm{~h}$. The reaction mixture was poured into a mixed solution of methanol/ aqueous $2 \mathrm{M} \mathrm{HCl}(\mathrm{v} / \mathrm{v}=9 / 1)$ in a beaker. The resulting precipitates were collected by suction filtration and washed first with water and then with acetone. After the resulting solid was dissolved in $\mathrm{CHCl}_{3}$, the residual solid was removed using Celite filtration. Chloroform was removed under reduced pressure to yield a pale yellow solid. The crude solid was purified with recycling preparative HPLC to produce macrocycle-bearing poly(ether ketone) 12 as brown films with moderate yields.

Poly(ether ketone) 12a: Yield 68\%. ${ }^{1} \mathrm{H}-\mathrm{NMR} \delta\left(400 \mathrm{MHz}, \mathrm{CDCl}_{3}\right): 3.81(6 \mathrm{H}, \mathrm{s})$, $6.86(4 \mathrm{H}, \mathrm{d}, J=8.4 \mathrm{~Hz}), 6.99-7.12(38 \mathrm{H}, \mathrm{m}), 7.34(2 \mathrm{H}, \mathrm{d}, J=9.6 \mathrm{~Hz}), 7.37(2 \mathrm{H}$, $\mathrm{d}, J=9.6 \mathrm{~Hz}), 7.50-7.58(12 \mathrm{H}, \mathrm{m}), 7.61-7.63(4 \mathrm{H}, \mathrm{m}), 7.66-7.70(6 \mathrm{H}, \mathrm{m})$, $7.82(4 \mathrm{H}, \mathrm{d}, J=7.2 \mathrm{~Hz}), \quad 7.84(4 \mathrm{H}, \mathrm{d}, J=7.6 \mathrm{~Hz}), 8.06(2 \mathrm{H}, \mathrm{d}, J=9.2 \mathrm{~Hz})$, $8.08(2 \mathrm{H}, \quad$ d, $J=9.6 \mathrm{~Hz}), \quad 8.35(2 \mathrm{H}, \quad$ s $), \quad 8.37\left(2 \mathrm{H}, \quad\right.$ s) $\quad$ p.p.m. ${ }^{13} \mathrm{C}-\mathrm{NMR} \quad \delta$ $\left(100 \mathrm{MHz}, \mathrm{CDCl}_{3}\right): 56.6,114.4,116.6,117.2,117.7,118.7,119.2,120.1$, $120.2,120.3,121.7,122.0,125.0,125.6,125.8,126.6,127.2,127.9,128.3$, $128.4,129.8,131.1,131.4,131.7,131.9,132.1,132.4,132.5,132.9,134.7$, $135.4,135.7,136.8,150.7,151.0,153.3,153.8,154.1,154.8,156.6,156.8$, $160.2,161.3,161.7,162.1,193.9,194.9,195.2$ p.p.m. IR $v(\mathrm{KBr}): 1235,1593$, $1654 \mathrm{~cm}^{-1}$. Anal. calcd. for $\left(\mathrm{C}_{144} \mathrm{H}_{90} \mathrm{O}_{19}\right)_{\mathrm{n}}$ : C, 81.42; H, 4.27. Found: C, 80.48; $\mathrm{H}, 4.55 \%$.

Poly (ether ketone) 12b: Yield 72\%. ${ }^{1} \mathrm{H}-\mathrm{NMR} \delta\left(400 \mathrm{MHz}, \mathrm{CDCl}_{3}\right)$ : $3.81(6 \mathrm{H}, \mathrm{s}), 6.77-6.90(4 \mathrm{H}, \mathrm{m}), 6.92-7.16(42 \mathrm{H}, \mathrm{m}), 7.30-7.40(4 \mathrm{H}, \mathrm{m}), 7.43-$
7.74(22H, m), 7.76-7.90(8H, m), 7.98-8.12(4H, m), 8.36(2H, s), 8.38(2H, s) p.p.m. ${ }^{13} \mathrm{C}-\mathrm{NMR} \delta\left(100 \mathrm{MHz}, \mathrm{CDCl}_{3}\right): 56.5,114.4,116.6,117.2,117.7,118.5$, $118.7,120.0,120.1,120.3,120.5,121.7,121.9,124.9,125.6,126.6,126.8,127.2$, $127.9,128.2,128.3,128.7,129.8,131.4,131.6,131.9,132.1,132.4,132.5,132.8$, 134.7, 135.1, 135.7, 136.8, 150.7, 150.9, 152.5, 153.3, 153.8, 154.0, 154.7, 156.8, $157.2,160.2,161.2,161.7,162.0,193.8,194.9,195.1$ p.p.m. IR $v(\mathrm{KBr}): 1239$, 1593, $1653 \mathrm{~cm}^{-1}$. Anal. calcd. for $\left(\mathrm{C}_{150} \mathrm{H}_{94} \mathrm{O}_{20}\right)_{\mathrm{n}}$ : C, 81.29; H, 4.27. Found: $\mathrm{C}$, $78.92 ; \mathrm{H}, 4.51 \%$.

Poly(ether ketone) 12c: Yield 74\%. ${ }^{1} \mathrm{H}-\mathrm{NMR} \delta\left(400 \mathrm{MHz}, \mathrm{CDCl}_{3}\right)$ : $3.81(6 \mathrm{H}, \mathrm{s}), 6.71-6.77(3 \mathrm{H}, \mathrm{m}), 6.86(4 \mathrm{H}, \mathrm{d}, J=8.8 \mathrm{~Hz}), 6.99-7.12(34 \mathrm{H}, \mathrm{m})$, 7.24-7.28(2H, m), 7.33-7.37(7H, m), 7.51-7.69(22H, m), 7.81-7.83(8H, m), $8.04-8.09(4 \mathrm{H}, \mathrm{m}), 8.35(2 \mathrm{H}, \mathrm{s}), 8.37\left(2 \mathrm{H}\right.$, s) p.p.m. ${ }^{13} \mathrm{C}-\mathrm{NMR} \delta(100 \mathrm{MHz}$, $\left.\mathrm{CDCl}_{3}\right): 56.6,109.4,113.3,114.4,116.6,117.0,117.3,117.7,118.7,119.1,120.0$, $120.1,120.2,121.3,121.7,122.0,122.2,124.9,125.6,126.6,126.9,127.2,127.9$, 128.6, 129.8, 130.1, 130.5, 131.4, 131.7, 131.9, 132.1, 132.4, 132.5, 132.9, 134.7, $135.7,136.6,142.1,150.7,150.9,153.3,153.8,154.0,155.3,156.8,157.1,158.5$, 160.2, 161.1, 161.7, 162.1, 193.8, 194.9, 195.2 p.p.m. IR $v(\mathrm{KBr}): 1239,1594$, $1654 \mathrm{~cm}^{-1}$. Anal. calcd. for $\left(\mathrm{C}_{150} \mathrm{H}_{94} \mathrm{O}_{20}\right)_{\mathrm{n}}$ : C, 81.29; H, 4.27. Found: C, 79.57; $\mathrm{H}, 4.20 \%$.

\section{RESULTS AND DISCUSSION}

\section{Synthesis of macrocyclic precursors 6 and 9}

The $\mathrm{AlCl}_{3}$-mediated Friedel-Crafts acylation reaction of 4-bromodiphenyl ether (2) with 4-fluorobenzoyl chloride (3) in 1,2-dichloroethane proceeded at the $4^{\prime}$-position of ether 2 regioselectively to produce fluoride 4 with $85 \%$ yield. The nucleophilic aromatic substitution reaction of $(S)$-BINOL (1) with fluoride 4 in DMF produced the corresponding disubstituted binaphthyl (5) with $74 \%$ yield. The direct condensation of the binaphthyl (5) with 4-fluorobenzoic acid mediated by $\mathrm{P}_{2} \mathrm{O}_{5}-\mathrm{MsOH}$ proceeded at 6,6'-positions regioselectively to produce macrocyclic precursor 6 with $57 \%$ yield. The decrease in

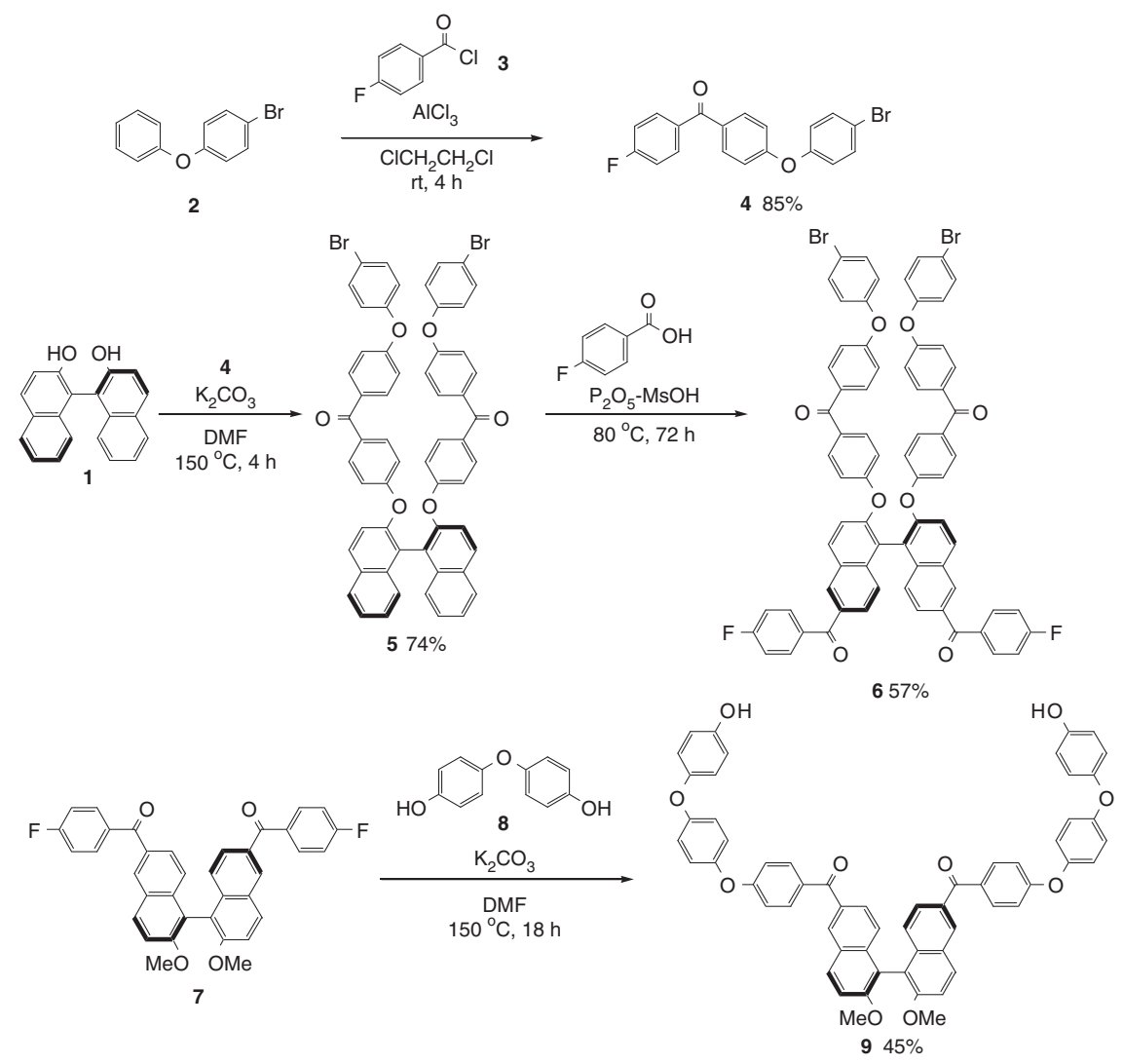

Scheme 1 Preparation of macrocyclic precursors 6 and $\mathbf{9}$. 
the yield is probably due to the lower reactivity of the binaphthyl units containing benzophenone structures, which require a higher temperature and a longer reaction time.

The other macrocyclic precursor (9) was prepared through nucleophilic aromatic substitution reaction of (S)-6,6'-bis(4-fluorobenzoyl)$2,2^{\prime}$-dimethoxy-1,1'-binaphthyl $(7)^{4}$ with 6 equimolar amounts of $4,4^{\prime}$-oxybiphenol (8) under high dilution conditions. Pure macrocyclic precursor 9 was obtained with $45 \%$ yield after using recycling preparative HPLC purification (Scheme 1).

\section{Cyclization}

Cyclization between macrocyclic precursors 6 and 9 under high dilution conditions proceeded to produce macrocycle 10 with $20 \%$ yield after recycling preparative HPLC and preparative PLC purification. Figure 1 shows ${ }^{1} \mathrm{H}-\mathrm{NMR}$ spectra of precursors $6 / 9$ and macrocycle 10. A triplet signal that is assigned to the proton $\mathrm{H}_{c}$ of precursor 6 disappears completely in the spectrum of macrocycle 10. In addition, a doublet signal that is assigned to the proton $\mathrm{H}_{\mathrm{d}}$ of precursor 9 also disappears completely in the spectrum of $\mathbf{1 0}$. The peak positions of the singlet signals observed under the lowest magnetic field in the spectra of precursors $\mathbf{6}$ and $\mathbf{9}$, that is, $\mathrm{H}_{\mathrm{a}}$ and $\mathrm{H}_{\mathrm{b}}$, shift to lower magnetic fields in the spectrum of macrocycle 10, that is, $\mathrm{H}_{\mathrm{a}}^{\prime}$ and $\mathrm{H}_{\mathrm{b}}^{\prime}$. Furthermore, the MALDI TOF-MASS measurement of the resulting product (measured $m / z=2113.3$ ) proved that the product is macrocycle $\mathbf{1 0}$.

\section{Suzuki coupling polymerization}

Macrocycle-bearing monomer $\mathbf{1 0}$ was allowed to react with diboric acid pinacol diester 11a in the presence of $20 \mathrm{~mol} \%$ of $\mathrm{Pd}\left(\mathrm{PPh}_{3}\right)_{4}$ against monomer 10 and $\mathrm{K}_{2} \mathrm{CO}_{3}$ in DMF for $24 \mathrm{~h}$, producing the corresponding macrocycle-bearing poly(ether ketone) (12a) with $64 \%$ yield (Table 1, run 1). When the reaction time was lengthened to $48 \mathrm{~h}$, the yield increased slightly (run 2). Even when a $10 \mathrm{~mol} \%$ catalyst was used, high-molecular-weight poly(ether ketone) 12a was obtained with a moderate yield (run 4).

Polymerization of macrocycle-bearing monomer 10 with diboric diester $\mathbf{1 1 b}$ /c yielded the corresponding macrocycle-bearing poly(ether ketone)s $12 \mathrm{~b} / \mathrm{c}$. When diboric acid esters $11 \mathbf{b}$ and $11 \mathrm{c}$ were used, highmolecular-weight polyketones $\mathbf{1 2 b} / \mathbf{c}$ were obtained (runs 5 and 6). In addition, molecular weights of poly(ether ketone)s $12 \mathbf{a}-\mathbf{c}$ in this study are much higher than those of wholly aromatic polyketones $\left(M_{\mathrm{n}}\right.$ : 5000-6400) synthesized through nickel complex-mediated aromatic homo-coupling polymerization, previously reported. ${ }^{15}$ The difference between these polymerization behaviors probably depends on the length of the linkers that connect the macrocycles. The macrocycles are so large and bulky that homo-coupling polymerization with nearby neighboring macrocycles would be disadvantageous for producing the polymer. Instead, with cross-coupling polymerization the neighboring macrocycles are further apart, which leads to smooth polymerization (Scheme 2).

\section{Property}

The glass transition temperatures $\left(T_{\mathrm{g}} \mathrm{s}\right)$ of the resulting poly(ether ketone)s (12a-c) are 256, 257 and $220^{\circ} \mathrm{C}$, respectively (Table 2). The $T_{\mathrm{g}}$ of poly(ether ketone) $12 \mathrm{c}$ is relatively lower than those of poly (ether ketone)s 12a and 12b. Presumably, this variation in $T_{\mathrm{g}}$ is due to the introduction of $m$-phenylenedioxy units with bent structures, which would decrease the rigidity of polymer main chains. Poly(ether ketone)s (12a-c) have much higher $T_{\mathrm{g}} \mathrm{s}$ than poly(ether ether ketone) $143^{\circ} \mathrm{C}$ ) and the other aromatic polyketones included in our studies. The incorporation of rigid macrocycles may suppress the free rotation
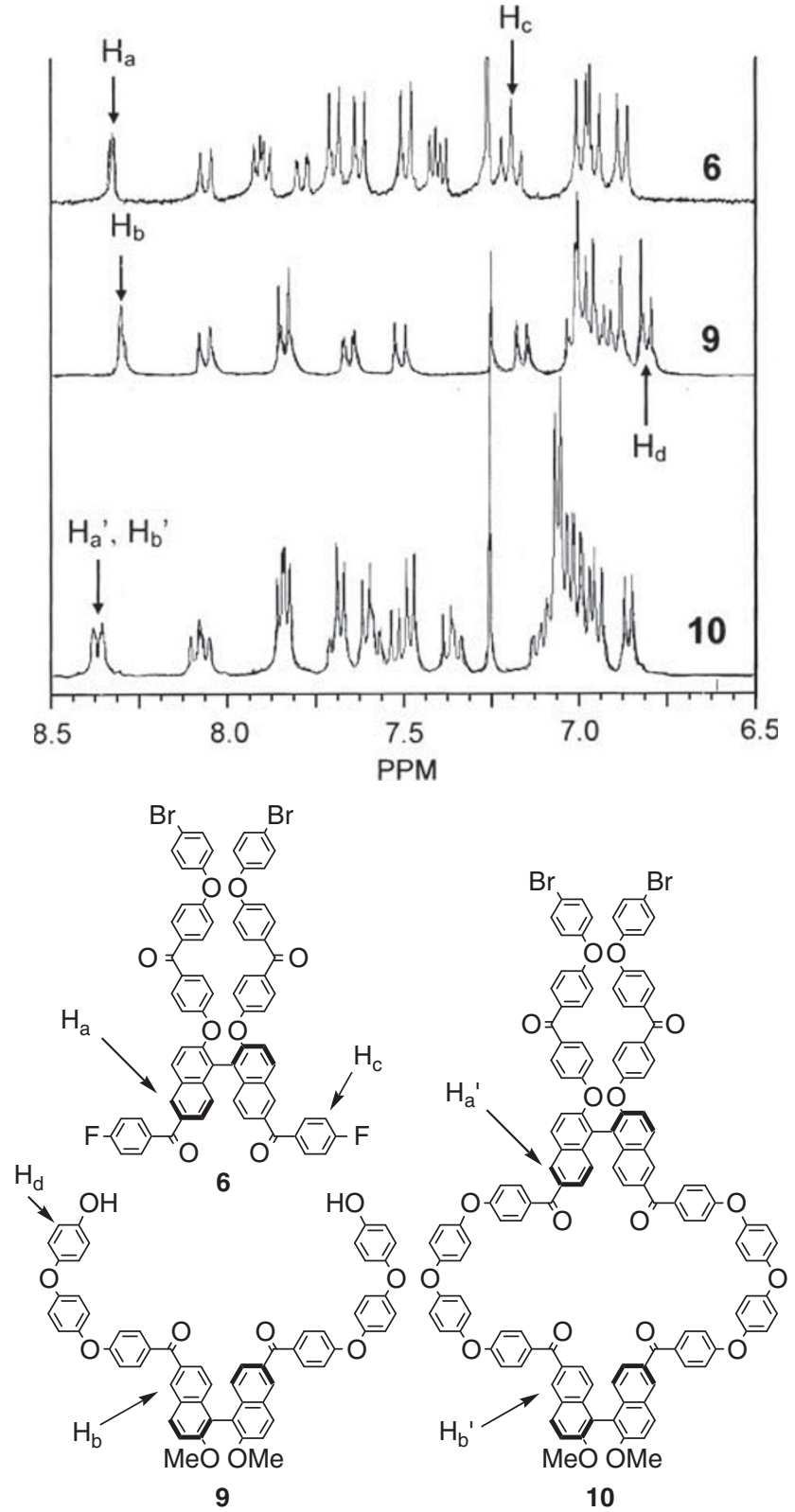

Figure $1^{1} \mathrm{H}$-NMR spectra of 6,9 and 10 . NMR, nuclear magnetic resonance.

Table 1 Suzuki coupling polymerization of macrocycle-bearing monomer 10 with $11 a-c$

\begin{tabular}{lcccccc}
\hline Run & 11 & Base & $P d\left(P P h_{3}\right)_{4}(m m o l)$ & Time $(h)$ & Yield (\%) & $M_{n}{ }^{\mathrm{a}}$ \\
\hline 1 & $11 \mathbf{a}$ & $\mathrm{K}_{2} \mathrm{CO}_{3}$ & 0.01 & 24 & $64(\mathbf{1 2 a})$ & 13000 \\
2 & & $\mathrm{~K}_{2} \mathrm{CO}_{3}$ & 0.01 & 48 & 68 & 13000 \\
3 & & $\mathrm{C}_{2} \mathrm{CO}_{3}$ & 0.01 & 48 & 64 & 12000 \\
4 & & $\mathrm{~K}_{2} \mathrm{CO}_{3}$ & 0.025 & 48 & 60 & 11000 \\
5 & $11 \mathbf{b}$ & $\mathrm{K}_{2} \mathrm{CO}_{3}$ & 0.01 & 48 & $72(\mathbf{1 2 b})$ & 19000 \\
6 & $11 \mathrm{c}$ & $\mathrm{K}_{2} \mathrm{CO}_{3}$ & 0.01 & 48 & $74(12 \mathrm{c})$ & 17000 \\
\hline
\end{tabular}

Abbreviations; GPC, gel-permeation chromatography; Pd, palladium.

Reaction conditions: macrocycle-bearing monomer $10(0.05 \mathrm{mmol})$, diboric acid diester $11 \mathrm{a}-\mathrm{c}$ $(0.05 \mathrm{mmol}), \mathrm{K}_{2} \mathrm{CO}_{3}(0.3 \mathrm{mmol}), \mathrm{Pd}\left(\mathrm{PPh}_{3}\right)_{4}(0.01 \mathrm{mmol})$, DMF $(0.5 \mathrm{ml})$. a Estimated by GPC (eluent; $\mathrm{CHCl}_{3}$ ) on the basis of polystyrene standards. 


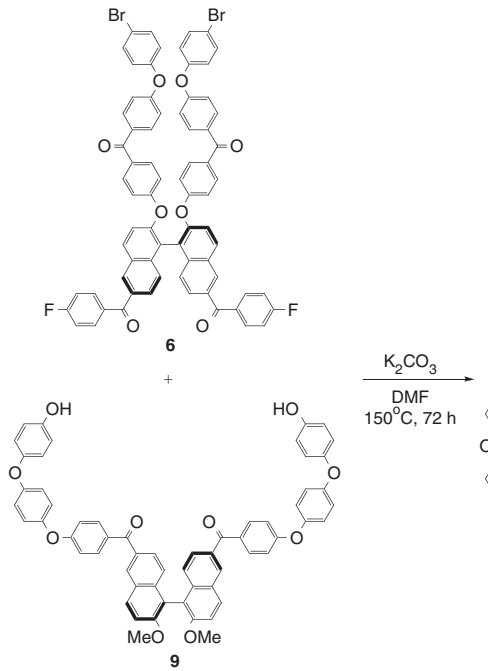

Scheme 2 Cyclization and Suzuki coupling polymerization.

Table 2 Thermal and optical properties of poly(ether ketone)s $12 \mathrm{a}-\mathrm{c}$

\begin{tabular}{lcccc}
\hline Polymer 12 & $T_{g}\left({ }^{\circ} \mathrm{C}\right)^{\mathrm{a}}$ & $T_{d 5}\left({ }^{\circ} \mathrm{C}\right)^{\mathrm{b}}$ & {$[\alpha] b^{5}(\mathrm{deg})$} & $[\Phi]]^{5}(\mathrm{deg})$ \\
\hline 12a & 256 & 435 & +93 & +1976 \\
$12 \mathrm{~b}$ & 257 & 437 & +86 & +1906 \\
$12 \mathrm{c}$ & 220 & 427 & +88 & +1950 \\
\hline
\end{tabular}

aDetermined on the basis of DSC curves. Heating rate: $10 \mathrm{~K} \mathrm{~min}^{-1}$.

bTemperature where a $5 \%$ weight loss occurs. Heating rate: $10 \mathrm{~K} \mathrm{~min}^{-1}$.

cMeasured in $\mathrm{CHCl}_{3}\left(5.0 \times 10^{-5} \mathrm{~mol} \mathrm{I}^{-1}\right)$.

Table 3 Solubility of poly(ether ketone)s $12 a-c$

\begin{tabular}{lccccccc}
\hline Polymer & $\mathrm{CHCl}_{3}$ & $m$-Cresol & THF & DMSO & DMF & NMP & $\mathrm{H}_{2} \mathrm{SO}_{4}$ \\
\hline $12 \mathrm{a}$ & ++ & \pm & ++ & \pm & ++ & ++ & \pm \\
$12 \mathrm{~b}$ & ++ & \pm & ++ & + & ++ & ++ & \pm \\
$12 \mathrm{c}$ & ++ & \pm & ++ & + & ++ & ++ & \pm \\
\hline
\end{tabular}

Solubility: $(++)$ : soluble at room temperature. $(+)$ : soluble upon heating. $( \pm)$ : partially soluble or swelling. (-): insoluble.

of the polymer main chains. In addition, the $T_{\mathrm{g}} \mathrm{s}$ of poly(ether ketone)s $(\mathbf{1 2 a}-\mathbf{c})$ are much higher than those of macrocycle-bearing wholly aromatic polyketones $\left(176-178^{\circ} \mathrm{C}\right)$ synthesized through homo-coupling polymerization, previously reported. ${ }^{15}$ The reasons for this variation in $T_{\mathrm{g}}$ are the increase in molecular weight and the difference of the connecting positions of binaphthylene units, that is, $2,2^{\prime}$-positions or $6,6^{\prime}$-positions. Polymers bearing binaphthyl-2,2'-ene groups will be more rigid than those bearing binaphthyl-6,6'-ene groups according to the difference in steric hindrance. The temperature range at which $5 \%$ weight losses occur $\left(T_{\mathrm{d} 5}\right)$ for poly(ether ketone)s 12a-c is $427-435^{\circ} \mathrm{C}$ (Table 2). Although poly(ether ketone)s $(12 \mathrm{a}-\mathrm{c})$ have very high $T_{\mathrm{g}} \mathrm{s}$, they are soluble in typical organic solvents, such as chloroform and DMF (Table 3 ). By incorporating macrocycles that include twisted binaphthyl-2,2'-ene units, packing effects between polymer chains will be minimized.

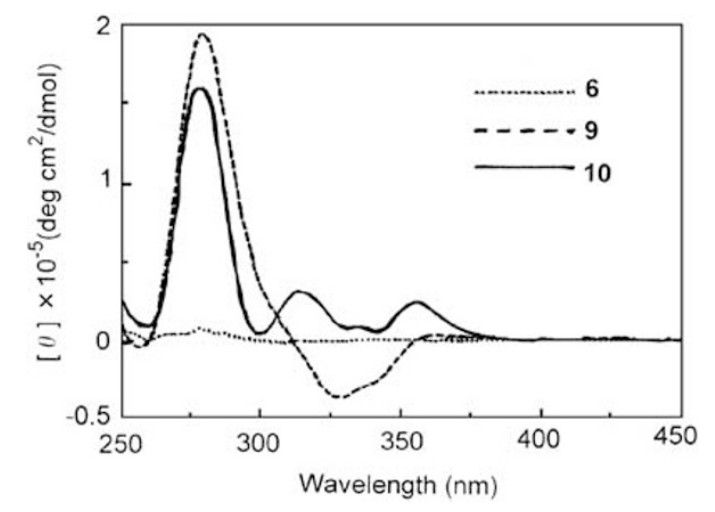

Figure $2 C D$ spectra of precursors 6 and $\mathbf{9}$, macrocycle 10. CD, circular dichromism.

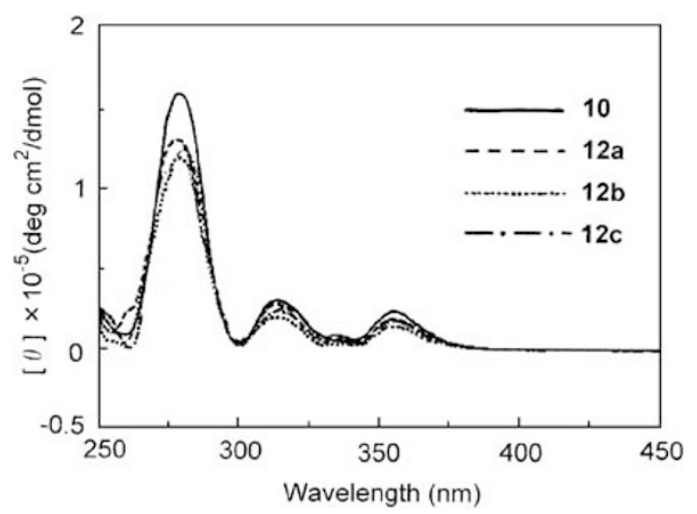

Figure $3 \mathrm{CD}$ spectra of macrocycle 10 and poly(ether ketone)s $12 \mathrm{a}-\mathrm{c}$. CD, circular dichromism. 
In addition, poly(ether ketone)s $\mathbf{1 2 a}-\mathbf{c}$ have sufficient molar rotations $\left([\Phi]_{\mathrm{D}}^{25}\right.$ in $\mathrm{CHCl}_{3}$, Table 2). Figures 2 and 3 show $\mathrm{CD}$ spectra of precursors 6/9, macrocycle 10 and macrocycle-bearing poly(ether ketone)s 12a-c. Although no clear peaks were observed in the CD spectrum of precursor 6, clear peaks were observed at $\sim 280 \mathrm{~nm}$ in those of precursor 9, macrocycle $\mathbf{1 0}$ and macrocycle-bearing poly(ether ketone)s 12a-c. These results suggest that macrocycle $\mathbf{1 0}$ and macrocycle-bearing poly(ether ketone)s 12a-c have optically active cyclic structures. Poly(ether ketone)s 12a-c may be useful for fine molecular recognition of optically active molecules using optically active cavities.

\section{CONCLUSIONS}

Macrocycle-bearing monomer 10 was synthesized through nucleophilic aromatic substitution cyclization of precursors $\mathbf{6}$ and $\mathbf{9}$ using high dilution conditions. Pd-catalyzed Suzuki coupling polymerization of macrocycle-bearing monomer $\mathbf{1 0}$ with diboric acid pinacol esters 11a-c produced aromatic poly(ether ketone)s with optically active macrocycles (12a-c). Poly(ether ketone)s 12a-c have high glasstransition temperatures $\left(T_{\mathrm{g}}: 220-257^{\circ} \mathrm{C}\right)$, large molar rotations $\left([\Phi]_{\mathrm{D}}^{25}:+1906-1976 \mathrm{deg}\right)$ and excellent solubility in typical solvents, such as $\mathrm{CHCl}_{3}$ and DMF. The improvement in thermal stability and maintenance of solubility in organic solvents by the incorporation of rigid macrocycles to polymer side chains will be a useful tool in the molecular designs used in the development of polymer materials with excellent thermal stability and excellent solubility in organic solvents.

\section{CONFLICT OF INTEREST}

The authors declare no conflict of interest.

\section{ACKNOWLEDGEMENTS}

This study is supported by a Grant-in-Aid for Young Scientists (B) (no. 20750173) from the Ministry of Education, Culture, Sports, Science and Technology of Japan. We are grateful to Professor Toshikazu Takata at the Tokyo Institute of Technology for measurement of the CD spectra.
1 Staniland, P. A., Eastmond, G. C., Ledwith, A., Russo, S. \& Sigwalt, P. (ed.) Comprehensive Polymer Science Vol. 5, 483 (Pergamon Press, Oxford, UK, 1989.

2 Maeyama, K. Synthesis of wholly aromatic polyketones based on fine molecular designing. J. Synth. Org. Chem. 69, 616-626 (2005).

3 Maeyama, K. Aromatic poly(ether ketone)s functional materials. Expect Mater Future 8, 42-47 (2008)

4 Maeyama, K., Hikiji, I., Ogura, K., Okamoto, A., Ogino, K., Saito, H. \& Yonezawa, N. Synthesis of optically active aromatic poly(ether ketone)s via nucleophilic aromatic substitution polymerization. Polym. J. 37, 707-710 (2005).

5 Maeyama, K., Maeda, S., Ogino, K., Saito, H. \& Yonezawa, N. Synthesis of optically active aromatic poly(ether ketone)s containing 2,2'-bis(4-benzoylphenoxy)1,1'-binaphthyl-6,6'-ene backbones. React. Funct. Polym. 65, 229-237 (2005).

6 Maeyama, K., Tsukamoto, T., Suzuki, M., Higashibayashi, S. \& Sakurai, H. Synthesis of aromatic polyketones bearing 1,1'-Binaphthyl-2,2'-dioxy units through Suzuki-Miyaura coupling polymerization. Chem. Lett. 40, 1445-1446.

7 Maeyama, K., Ogura, K., Okamoto, A., Ogino, K., Saito, H. \& Yonezawa, N. Nickel complex-mediated synthesis of optically active wholly aromatic polyketones bearing 2,2'-Dimethoxy-1,1'-binaphthylene units. Polym. J. 37, 736-741 (2005).

8 Okamoto, A., Mitsui, R., Maeyama, K., Saito, H., Oike, H., Murakami, Y. \& Yonezawa, N. Electrophilic aromatic aroylation polycondensation synthesis of wholly aromatic polyketones composed of 2,2'-dimethoxy-1,1'-binaphthylene moiety. React. Funct. Polym. 67, 1243-1251 (2007).

9 Cao, H., Liu, X., Ben, T., Chen, C., Gao, Z. \& Zhang, W. Synthesis and characterization of rigid cyclic oligomer containing thioether moiety. Polym. Prep. 43, 1112-1113 (2002).

10 Dang, G., Yang, W., Zhao, X., Chen, C., Li, F., Zhang, W. \& Wu, Z. Molecular design and synthesis of a novel aromatic macrocycle with a $\left[1,1^{\prime}\right]$ binaphthalenyl moiety and a $p$ chlorophenyl substituent. Polym. Prep. 44, 911 (2003).

11 Wang, X., Liu, N., Cao, H., Liu, W., Chen, C., Zhang, W. \& Wei, Y. Chiral crystal structure of racemic binaphthyl poly(ether ketone) macrocycles. Macromol. Rapid Commun. 26, 554-557 (2005).

12 Liu, N., Wang, X., Jin, E., Chen, C., Zhang, W. \& Wei, Y. Synthesis and self-assembly of comb oligomers having rigid racemic or chiral binaphthyl macrocyclic pendant groups. Polymer 47, 3021-3027 (2006).

13 Ema, T., Tanida, D., Sugita, K., Sakai, T., Miyazawa, K. \& Ohnishi, A. Chiral selector with multiple hydrogen-bonding sites in a macrocyclic cavity. Org. Lett. 10, 2365-2368 (2008).

14 Maeda, S., Maeyama, K. \& Yonezawa, N. Synthesis of optically active Bis(binaphthyl) macrocycles. Synth. Commun. 37, 2663-2770 (2007).

15 Maeyama, K., Maeda, S., Saito, H. \& Yonezawa, N. Synthesis of wholly aromatic polyketones containing optically active macrocycles. Polym. J. 39, 342-346 (2007).

16 Maeyama, K., Yamashita, K., Maeda, S., Yonezawa, N., Aikawa, S. \& Yoshida, Y. Synthesis of optically active aromatic ether ketone macrocycles containing 2,2'-dimethoxy-1,1'-binaphthyl-6,6'-diyl moieties. Synth. Commun. 39, 4158-4170 (2009).

17 Miyaura, N. \& Suzuki, A. Palladium-catalyzed cross-coupling reactions of organoboron compounds. Chem. Rev. 95, 2457-2483 (1995).

18 Eaton, P. E., Carlson, G. R. \& Lee, G. T. Phosphorus pentoxide-methanesulfonic acid: Convenient alternative to polyphosphoric acid. J. Org. Chem., 38, 4071-4073 (1973). 